\title{
PENGARUH BIOLOGICAL ASSET INTENSITY, KONSENTRASI KEPEMILIKAN DAN PROFITABILITAS TERHADAP PENGUNGKAPAN ASET BIOLOGIS
}

\author{
Chilma Zufriya, Negina Kencono Putri, Yusriati Nur Farida \\ Universitas Jenderal Soedirman, Banyumas, Indonesia \\ chilmazufriya22@gmail.com, negina.putri@unsoed.ac.id, \\ yusriati_nur_farida@yahoo.com \\ https://doi.org/10.46367/jas.v4i2.252
}

Received: Nov 03, 2020 Revised: Nov 27, 2020 Accepted: Dec 12, 2020 Published: Dec 16, 2020

\begin{abstract}
Agricultural companies need to disclose biological assets because biological assets are the main assets owned by the company. Some factors that influence the disclosure of biological assets include biological asset intensity, ownership concentration, company size, type of public accounting firm, and profitability. The purpose of this study is to examine and analyze the effect of Biological Asset Intensity, Ownership Concentration, and Profitability on Biological Asset Disclosure. This research is a type of quantitative research and the data source used is secondary data in the form of annual financial statements of agricultural companies for the period of 2016 to 2018. The data analysis technique used is descriptive statistics and regression analysis. Based on the results of research and data analysis shows that biological asset intensity does not affect disclosure of biological assets; concentration of ownership does not affect disclosure of biological asset; profitability does not affect disclosure of biological asset.
\end{abstract}

Keywords: Biological Asset Intensity, Ownership Concentration, Profitability, Disclosure of Biological Asset.

\begin{abstract}
ABSTRAK
Perusahaan agrikultur perlu melakukan pengungkapan atas aset biologis, karena aset biologis merupakan aset utama yang dimiliki perusahaan. Beberapa faktor yang mempengaruhi pengungkapan aset biologis antara lain: biological asset intensity, konsentrasi kepemilikan, ukuran perusahaan, jenis Kantor Akuntan Publik (KAP), dan profitabilitas. Tujuan penelitian ini yaitu untuk menguji dan menganalisis pengaruh Biological Asset Intensity, Konsentrasi Kepemilikan, dan Profitabilitas terhadap Pengungkapan Aset Biologis. Penelitian ini merupakan jenis penelitian kuantitatif dan sumber data yang digunakan adalah data sekunder berupa laporan keuangan tahunan perusahaan agrikultur periode 2016-2018. Teknik analisis data yang digunakan adalah statistik deskriptif dan analisis regresi. Berdasarkan hasil penelitian dan analisis data menunjukkan bahwa biological asset intensity tidak berpengaruh terhadap pengungkapan aset biologis; konsentrasi kepemilikan tidak berpengaruh terhadap pengungkapan aset biologis; profitabilitas tidak berpengaruh terhadap pengungkapan aset biologis.
\end{abstract}

Kata Kunci: Biological Asset Intensisty, Konsentrasi Kepemilikan, Profitabilitas, Pengungkapan Aset Biologis. 


\section{PENDAHULUAN}

Dewasa ini, pelaporan keuangan yang sesuai dengan standar semakin mengalami peningkatan. Hal tersebut terutama terjadi pada perusahaan publik, dimana tingkat kepatuhan emiten terhadap standar semakin baik dari tahun ke tahun, baik standar yang ditetapkan oleh pembuat standar akuntansi keuangan maupun standar lain yang ditetapkan oleh otoritas bursa (Birch and Tyfield 2013; Gonçalves and Lopes 2014; Yurniwati et al. 2018). Dewan Standar Akuntansi Keuangan (DSAK) Ikatan Akuntan Indonesia (IAI) telah mengesahkan Pernyataan Standar Akuntansi Keuangan (PSAK) 69 yang merupakan adopsi dari Internaional Accounting Standard (IAS) 41 (IAI 2018). DSAK IAI sepakat untuk memberikan kelonggaran tanggal efektif penerapan PSAK 69 selama satu tahun yaitu dari 1 Januari 2017 menjadi 1 Januari 2018, dengan opsi penerapan dini diperkenankan.

Kebijakan tersebut diambil dengan mempertimbangkan untuk memberikan waktu yang lebih panjang kepada industri agrikultur untuk dapat mempersiapkan diri dalam membuat analisis dampak penerapan PSAK 69 terhadap laporan keuangannya. Aset biologis (biological asset) menurut PSAK 69 adalah hewan atau tanaman hidup. Jadi, dapat dikatakan bahwa aset biologis adalah aset berupa makhluk hidup yang mengalami proses transformasi biologis (biological transformation) yang terdiri dari proses pertumbuhan, degenerasi, produksi, dan prokreasi yang mengakibatkan perubahan kualitatif atau kuantitaif aset biologis.

Adapun beberapa faktor yang mempengaruhi pengungkapan aset biologis telah diuji oleh penelitian sebelumnya (Gonçalves and Lopes 2014; Yurniwati et al. 2018; Duwu et al. 2018; Alfiani and Rahmawati 2019). Penelitian (Duwu et al. 2018; Gonçalves and Lopes 2014) mengemukakan bahwa faktor-faktor yang diduga mempengaruhi tingkat pengungkapan aset biologis yaitu: biological asset intensity, konsentrasi kepemilikan, ukuran perusahaan, jenis Kantor Akuntan Publik (KAP), dan profitabilitas.

Oleh sebab itu penelitian ini bertujuan untuk menguji dan menganalisis pengaruh biological asset intensity, konsentrasi kepemilikan, dan profitabilitas terhadap pengungkapan aset biologis pada perusahaan sektor agrikultur yang terdaftar di Bursa Efek Indonesia (BEI) tahun 2016-2018. Penelitian ini penting untuk dilakukan untuk menguji ketaatan perusahaan emiten yang memiliki asset biologis terhadap standar pelaporan.

\section{TELAAH LITERATUR}

\section{Aset Biologis}

Teori stakeholder merupakan teori yang menyatakan bahwa perusahaan harus memberikan manfaat kepada seluruh stakeholder-nya (pemegang saham, kreditor, konsumen, supplier, pemerintah, masyarakat, analis, dan pihak lain) dan bukan hanya menjadi perusahaan yang beroperasi untuk memenuhi kepentingannya sendiri (Freeman and McVea 2005). Berdasarkan PSAK 69: Agrikultur, pengungkapan aset yang dilakukan entitas adalah pengungkapan deskripsi kuantitatif aset biologis dibedakan menjadi aset biologis yang dapat dikonsumsi dan aset produktif (bearer biological asset), atau aset biologis yang menghasilkan (mature) dan yang belum menghasilkan (immature) (IAI 2018). 
Sementara, berdasarkan PSAK 69: Agrikultur, biological asset intensity pada perusahaan agrikultur menggambarkan proporsi investasi yang dimiliki perusahaan terhadap aset biologisnya. Biological asset intensity atau intensitas aset biologis merupakan jumlah proporsi investasi pada aset biologis pada perusahaan agrikultur yang disajikan dalam catatan atas laporan keuangan (Bohušová and Bohusova 2016). Aset biologis didefinisikan sebagai persediaan jasa saat ini yang timbul dari produksi dan eksploitasi elemen dalam kerajaan hewan. Sektor pertanian di Indonesia memainkan peran penting karena telah memberikan kontribusi terhadap pertumbuhan dan penyumbang utama pendapatan nasional dan pendapatan ekspor. Namun, bidang ini mendapat sedikit perhatian dari para peneliti dan regulator hingga penerapan Standar Akuntansi Internasional (IAS 41). Item yang sering dilaporkan untuk penentu penelitian pengungkapan adalah jenis aset biologis dan rekonsiliasi nilai tercatat, tetapi item lain diabaikan seperti risiko manajemen dan batasan lainnya (IAI 2018).

Persyaratan pengungkapan aset biologis pada nilai wajar menjadi beban akuntan dan auditor, karena mereka terus menggunakan biaya historis dalam mengukur nilai aset biologis. Oleh karena itu, auditor memainkan peran penting dalam memastikan kepatuhan laporan keuangan. Pentingnya pengungkapan aset biologis dalam laporan keuangan digunakan untuk mempengaruhi pengambilan keputusan investor. Jadi, informasi akuntansi harus lebih andal, akurat dan relevan dengan adanya aset biologis. Dengan meningkatkan up-to-date informasi, dapat mengarah pada tingkat transparansi yang tinggi yang meningkatkan kemandirian investor pasar modal. Nilai wajar mencerminkan harga pasar saat ini yang akan memberikan indikasi yang lebih baik dari risiko saat ini (Obst and Vardon 2014; Mondelli and Klein 2014; Daly and Skaife 2016; Bohušová and Bohusova 2016).

\section{Intensitas Aset Biologis dan Pengungkapan Aset Biologis}

Intensitas aset biologis adalah kemampuan entitas untuk mengungkapkan kepatuhan aset biologis sesuai dengan standar akuntansi yang memberikan jumlah aset biologis yang signifikan. Secara umum, intensitas diartikan sebagai tingkat upaya perusahaan dalam memberikan informasi kepada pengguna laporan tahunan. Tingkat pengungkapan adalah kemampuan perusahaan mengungkapkan provisi atau kontinjensinya yang berpengaruh signifikan. Hasil penelitian menunjukkan bahwa stakeholders akan mendapatkan keuntungan yang tinggi jika mereka fokus pada perusahaan besar dengan tingkat biologis yang memiliki intensitas asset yang tinggi. Hal tersebut karena perusahaan-perusahaan menyajikan transparansi pengungkapan tingkat tinggi. Oleh karena itu, semakin tinggi intensitas aset biologis akan meningkatkan kadar pengungkapan asset biologis (Mondelli and Klein 2014; Daly and Skaife 2016; Selahudin et al. 2018). Beberapa penelitian menemukan bahwa terdapat hubungan yang positif antara intensitas aset biologis dan pengungkapan wajib. Karena intensitas aset nonkeuangan tinggi, perusahaan cenderung menggunakan nilai wajar karena hal tersebut meningkatkan informasi nilai kepada investor (Birch and Tyfield 2012; Cavalheiro et al. 2019).

\section{Biological Asset Intensity}

Semakin tinggi biological asset intensity yang dimiliki perusahaan, maka akan semakin tinggi pula tingkat pengungkapan yang harus dilakukan perusahaan 
atas asetnya. Sebagai perusahaan agrikultur, aset biologis merupakan aset utama yang dimiliki perusahaan. Tingkat biological asset intensity searah dengan tingkat pengungkapan aset biologis (Mondelli and Klein 2014; Daly and Skaife 2016). Penelitian yang menyatakan bahwa biological asset intensity berpengaruh terhadap pengungkapan aset biologis dilakukan oleh (Yurniwati et al. 2018; Putri and Siregar 2019; Hayati and Serly 2020; Azzahra et al. 2020). Sedangkan penelitian yang menyatakan bahwa biological asset intensity tidak berpengaruh terhadap pengungkapan aset biologis diteliti oleh (Gonçalves and Lopes 2014; Alfiani and Rahmawati 2019; Sa'diyah et al. 2019; Aliffatun and Sa'adah 2020). Berdasarkan uraian tersebut, mayoritas penelitian menyatakan bahwa biological asset intensity berpengaruh terhadap pengungkapan aset biologis maka dapat dibuat hipotesis pertama yaitu: biological asset intensity berpengaruh terhadap pengungkapan aset biologis.

\section{Konsentrasi Kepemilikan}

Semakin tinggi rasio konsentrasi kepemilikan yang dimiliki perusahaan, maka semakin rendah tingkat pengungkapan atas aset biologisnya. Hal tersebut terjadi karena perusahaan dengan kepemilikan terkonsetrasi yang tinggi akan menimbulkan masalah keagenan dan biaya agensi yang tinggi sebagai akibat dari tidak meratanya informasi atau pengungkapan yang dilakukan tidak secara maksimal (Birch and Tyfield 2013; Cavalheiro et al. 2019). Penelitian yang menyatakan bahwa konsentrasi kepemilikan berpengaruh terhadap pegungkapan aset biologis diteliti oleh (Riski et al. 2019; Aliffatun and Sa'adah 2020; Azzahra et al. 2020). Sedangkan penelitian yang menyatakan bahwa konsentrasi kepemilikan tidak berpengaruh terhadap pegungkapan aset biologis diteliti oleh (Gonçalves and Lopes 2014; Daly and Skaife 2016; Yurniwati et al. 2018; Cavalheiro et al. 2019; Alfiani and Rahmawati 2019; Putri and Siregar 2019). Berdasarkan uraian tersebut, mayoritas penelitian menyatakan bahwa konsentrasi kepemilikan tidak berpengaruh terhadap pegungkapan aset biologis maka dapat dibuat hipotesis kedua yaitu: konsentrasi kepemilikan tidak berpengaruh terhadap pengungkapan aset biologis.

\section{Profitabilitas}

Tingkat profitabilitas yang tinggi dapat memberikan kepercayaan yang kuat bagi stakeholder untuk mempercayakan investasinya pada perusahaan. Oleh karena itu, pengungkapan atas aset biologis perlu dilakukan untuk kepentingan pada laporan keuangan dan pertanggungjawaban perusahaan pada pengguna laporan keuangan (Birch and Tyfield 2013; Daly and Skaife 2016; Alfiani and Rahmawati 2019; Cavalheiro et al. 2019). Penelitian yang menyatakan bahwa profitabilitas berpengaruh terhadap pengungkapan aset biologis diteliti oleh (Riski et al. 2019). Sedangkan penelitian yang menyatakan bahwa profitabilitas tidak berpengaruh terhadap pengungkapan aset biologis diteliti oleh (Gonçalves and Lopes 2014; Daly and Skaife 2016; Selahudin et al. 2018; Cavalheiro et al. 2019; Alfiani and Rahmawati 2019; Gustria and Sebrina 2020). Berdasarkan uraian tersebut, mayoritas penelitian menyatakan bahwa profitabilitas tidak berpengaruh terhadap pengungkapan aset biologis maka dapat dibuat hipotesis ketiga yaitu: profitabilitas tidak berpengaruh terhadap pengungkapan aset biologis. 


\section{METODE PENELITIAN}

Penelitian ini termasuk ke dalam jenis penelitian kuantitatif dengan hipotesis yang bertujuan untuk menguji dan menganalisis pengaruh antara variabel independen terhadap variabel dependen. Jenis data yang digunakan dalam penelitian ini adalah kuantitatif berbentuk angka-angka atau jumlah dengan satuan ukur yang dapat diukur secara sistematik. Populasi dalam penelitian ini adalah perusahaan sektor agrikultur yang terdaftar di Bursa Efek Indonesia (BEI). Periode dalam penelitian ini adalah pada tahun 2016-2018. Tahun pengamatan dilakukan dari tahun 2016-2018 karena standar tentang pengungkapan asset biologis di Indonesia berlaku per tahun 2018 dengan pengungkapan awal diperkenankan.

Dalam penelitian ini yang menjadi sampel terpilih adalah perusahaan agrikultur yang terdaftar di Bursa Efek Indonesia (BEI) periode 2016-2018. Sampel dipilih dengan menggunakan metode pengambilan sampel secara purposive sampling. Adapun kriteria-kriteria dalam pengambilan sampel yaitu: (1) Perusahaan agrikultur yang terdaftar berturut-turut di Bursa Efek Indonesia (BEI) selama tahun 2016-2018; (2) Perusahaan agrikultur yang menerbitkan laporan keuangan tahunan yang telah diaudit dan telah dipublikasikan secara lengkap selama periode 2016-2018; (3) Laporan keuangan tahunan konsisten dinyatakan dalam mata uang rupiah (Rp) selama periode 2016-2018; (4) Laporan keuangan tahunan menyajikan informasi terkait variabel penelitian. Total jumlah data dalam penelitian ini adalah 20 perusahaan selama 3 tahun pengamatan. Sumber data yang digunakan dalam penelitian ini adalah dari laporan keuangan tahunan perusahaan agrikultur periode 2016-2018 yang dipublikasikan di website Busra Efek Indonesia (BEI) yaitu https://www.idx.co.id.

\section{Definisi Konseptual dan Operasional Variabel}

\section{Pengungkapan Aset Biologis}

Pengukuran pengungkapan aset biologis mengacu pada PSAK 69 yang terdapat 40 item pengungkapan. Item pengungkapan aset biologis terdapat pada Tabel 1. Luas pengungkapan dilakukan dengan membandingkan total skor yang diperoleh (n) dengan total skor yang diwajibkan menurut PSAK 69 atau dinyatakan dengan rumus index wallace sebagai berikut:

\section{Pengungkapan Aset Biologis = $($ Total Item yang Diungkapkan $\div 40) \times 100 \%$}

Keterangan:

$\mathrm{n} \quad=$ total item yang diungkapkan perusahaan

$40=$ total item yang diwajibkan menurut PSAK 69.

Tabel 1 Indeks Pengungkapan Aset Biologis Menurut PSAK 69

\begin{tabular}{clc}
\hline Paragraf & \multicolumn{1}{c}{ Indeks Pengungkapan } & Skor \\
\hline & Mandatory Items: & \\
40 & Keuntungan atau Kerugian yang timbul selama periode: & 1 \\
40 & Pengakuan awal aset biologis & 1 \\
40 & Pengakuan awal hasil agrikultur & 1
\end{tabular}


41 Gambaran dari setiap kelompok aset biologis 1

$42 \quad$ Penjelasan paragraf 41

42 Penjelasan pengukuran paragraf $41 \quad 1$

46 Penjelasan aktivitas perusahaan dengan masing-masing 1 kelompok aset biologis

46 Penjelasan tahapan pengukuran non keuangan:

46 Aset yang tersedia di akhir periode 1

46 Hasil agrikultur selama periode tersebut 1

47 Asumsi dan metode yang digunakan dalam menentukan 1 nilai wajar dari masing-masing produk agrikultur pada titik panen dan setiap kelompok aset biologis

48 Nilai wajar dikurangi biaya untuk menjual produk agrikultur 1 yang dipanen pada periode tersebut

49 Informasi terkait aset biologis yang dibatasi atau dijaminkan 1

49 Komitmen dalam pembangunan atau akuisisi aset biologis $\quad 1$

49 Strategi manajemen terkait resiko keuangan aset biologis 1

50 Penyesuaian terkait perubahan jumlah tercatat aset biologis 1 pada awal dan akhir periode

50 Rekonsiliasi yang meliputi desegregasi pengungkapan $\quad 1$ tambahan ketika nilai wajar tidak dapat diukur secara andal

54 Entitas mengukur dan mengungkapkan aset biologis berdasarkan biaya yang mereka tetapkan dikurangi akumulasi penyusutan dan akumulasi penurunan nilai

54 Gambaran aset biologis 1

54 Penjelasan mengapa nilai wajar tidak dapat diukur secara 1 andal

54 Perkiraan tingkat ketidaksesuaian nilai wajar 1

54 Metode penyusutan yang digunakan 1

54 Masa manfaat atau tarif penyusutan yang digunakan 1

54 Jumlah tercatat bruto dan akumulasi penyusutan 1 (akumulasi rugi penurunan nilai) pada awal dan akhir periode

55 Pengakuan keuntungan atau kerugian penjualan aset 1 biologis

55 Kerugian penurunan nilai, terkait penghentian 1

55 Reversal rugi penurunan nilai terkait penghentian 1

55 Penyusutan terkait pengehentian

56 Pengungkapan entitas terkait - Nilai wajar aset biologis yang sebelumnya diukur pada biaya yang ditetapkan dikurangi akumulasi penyusutan dan kerugian penurunan menjadi andal terukur selama periode berjalan

56 Gambaran aset biologis 1

56 Penjelasan mengapa nilai wajar telah diukur secara andal 1

56 Pengaruh perubahan tersebut 1

57 Pengungkapan entitas terkait - Hibah Pemerintah

57 Hibah pemerintah 1

57 Pengakuan terkait sifat dan tingkat hibah pemerintah dalam 1 laporan keuangan 
57 Kondisi yang terpenuhi dan kontijensi lainnya yang melekat 1 pada hibah pemerintah

57 Penurunan yang signifikan pada tingkat hibah pemerintah 1 Non-Mandatory but recommended items:

43 Gambaran perhitungan setiap kelompok aset biologis, yang membedakannya dengan:

$43 \quad$ Consumable and bearer asset

43 Aset dewasa dan belum dewasa

51 Jumlah perubahan nilai wajar dikurangi biaya untuk menjual, mempengaruhi laba atau rugi kerana perubahan fisik dan perubahan harga

51 Informasi ini disampaikan oleh aset biologis

NA Informasi mengenai penilaian efek

NA Informasi lebih lanjut

NA Asumsi harga masa depan dan biaya, serta mengungkapkan 1 analisis sensitivitas dengan beberapa parameter

\section{Biological Asset Intensity}

Biological asset intensity (intensitas aset biologis), merupakan rasio yang digunakan untuk menggambarkan seberapa besar proporsi investasi perusahaan terhadap aset biologis yang dimiliki serta mampu menggambarkan ekspektasi kas yang akan diterima jika aset tersebut dijual. Pengukuran biological asset intensity adalah sebagai berikut:

\section{Biological Asset Intensity = Aset Biologis $\div$ Total Aset}

Keterangan:

Aset Biologis = aset berupa hewan atau tanaman hidup yang dimiliki perusahaan

Total Aset = total aset yang dimiliki perusahaan agrikultur

\section{Konsentrasi Kepemilikan}

Konsentrasi kepemilikan merupakan suatu ukuran distribusi kekuasaan dalam pengambilan keputusan baik oleh pemilik atau manajer. Pengukuran konsentrasi kepemilikan adalah sebagai berikut:

\section{Konsentrasi Kepemilikan $=$ Pemilik Sekaligus Manajer $\div$ Total Jumlah Pemilik}

\section{Profitabilitas}

Pada penelitian ini profitabilitas diproksikan dengan Return on Equity (ROE) menggunakan rasio untuk menilai perusahaan dalam mencari laba dan menunjukkan tingkat efektivitas kinerja perusahaan.

\section{HASIL DAN PEMBAHASAN PENELITIAN}

\section{Uji Normalitas}

Berdasarkan Tabel 2 dapat diketahui bahwa nilai Asymp. Sig. (2-tailed) sebesar 0,200 >0,05. Hal ini berarti dapat dikatakan bahwa data penelitian berdistribusi normal dan lolos uji normalitas. $\mathrm{N}$ berjumlah 48 karena dari 60 
laporan keuangan (20 perusahaan x 3 tahun), yang tidak memiliki kelengkapan data sebanyak 12 laporan keuangan perusahaan selama 3 tahun.

Tabel 2 Hasil Uji Normalitas

One-Sample Kolmogorov-Smirnov Test

\begin{tabular}{llc}
\hline & & \multicolumn{2}{c}{ Standardized Residual } \\
\hline$N$ & & 48 \\
Normal Parameters $a, b$ & Mean &, 0000000 \\
& Std. Deviation &, 94531319 \\
Most Extreme & Absolute &, 079 \\
Differences & Positive &, 066 \\
& Negative &,- 079 \\
Test Statistic & &, 079 \\
Asymp. Sig. (2-tailed) & & $, 200 \mathrm{c}, \mathrm{d}$ \\
\hline
\end{tabular}

\section{Uji Multikolinearitas}

Tabel 3 Hasil Uji Multikolinearitas

\section{Coefficientsa}

\begin{tabular}{clcccc}
\hline \multirow{2}{*}{ Model } & & \multirow{2}{*}{ Sig. } & \multicolumn{2}{c}{ Collinearity Statistics } \\
& & & & Tolerance & VIF \\
\hline 1 & (Constant) & 8,088 &, 000 & & \\
& BAI & $-2,218$ &, 032 &, 874 & 1,144 \\
& KK & $-1,002$ &, 322 &, 913 & 1,095 \\
& ROE &,- 568 &, 573 &, 858 & 1,165 \\
\hline \multicolumn{2}{l}{ a. Dependent Variable: PAB } & & &
\end{tabular}

Berdasarkan Tabel 3 hasil uji multikolinearitas menunjukkan bahwa nilai tolerance $\geq 0,10$ dan nilai $\mathrm{VIF} \leq 10$, maka dapat dinyatakan tidak terdapat masalah multikolinearitas.

\section{Uji Heteroskedastisitas}

Tabel 4 Hasil Uji Heteroskedastisitas

\section{Coefficients $a$}

\begin{tabular}{lccccc}
\hline Model & $\begin{array}{c}\text { Unstandardized } \\
\text { Coefficients }\end{array}$ & $\begin{array}{c}\text { Standardized } \\
\text { Coefficients }\end{array}$ & $\boldsymbol{t}$ & Sig. \\
& $\boldsymbol{B}$ & Std. Error & Beta & & \\
\hline (Constant) &, 128 &, 039 & & 3,268 &, 002 \\
BAI &, 052 &, 328 &, 022 &, 158 &, 875 \\
KK &, 022 &, 024 &, 131 &, 935 &, 355 \\
ROE &,- 017 &, 030 &,- 083 &,- 573 &, 569 \\
\hline a. Dependent Variable: $P A B$ & & & &
\end{tabular}

Berdasarkan Tabel 4 hasil uji heteroskedastisitas menunjukkan bahwa nilai Sig. > 0,05, maka dapat dinyatakan tidak terdapat masalah heteroskedastisitas. 


\section{Uji Hipotesis}

Tabel 5 Hasil Regresi Linier

Coefficients $a$

\begin{tabular}{|c|c|c|c|c|c|}
\hline \multirow[t]{2}{*}{ Model } & \multicolumn{2}{|c|}{$\begin{array}{l}\text { Unstandardized } \\
\text { Coefficients }\end{array}$} & \multirow{2}{*}{$\begin{array}{c}\text { Standardized } \\
\text { Coefficients } \\
\text { Beta }\end{array}$} & \multirow[t]{2}{*}{$t$} & \multirow[t]{2}{*}{ Sig. } \\
\hline & $\boldsymbol{B}$ & Std. Error & & & \\
\hline 1 (Constant) & ,710 & ,088 & & 8,088 & ,000 \\
\hline BAI & $-1,408$ & 635 &,- 325 & $-2,218$ & 032 \\
\hline KK &,- 053 & 053 &,- 144 & $-1,002$ &, 322 \\
\hline ROE &,- 039 & 068 &,- 084 &,- 568 &, 573 \\
\hline
\end{tabular}

Berdasarkan Tabel 5 uji t dapat menunjukkan hasil bahwa variabel independen biological asset intensity (BAI) memiliki nilai sig. 0,032 $\leq 0,05$ dan nilai $\mathrm{t}-2,218$. Hasil tersebut menunjukkan bahwa secara parsial biological asset intensity (BAI) tidak berpengaruh terhadap pengungkapan aset biologis (PAB). Variabel independen konsentrasi kepemilikan (KK) memiliki nilai sig. 0,322 > 0,05 dan nilai $\mathrm{t}-1,002$. Hasil tersebut menunjukkan bahwa secara parsial konsentrasi kepemilikan tidak berpengaruh terhadap pengungkapan aset biologis (PAB). Variabel independen profitabilitas (ROE) memiliki nilai sig. 0,573>0,05 dan nilai $t-0,568$. Hasil tersebut menunjukkan bahwa secara parsial ROE tidak berpengaruh terhadap pengungkapan aset biologis (PAB).

\section{Uji Koefisien Determinan}

Tabel 6 Hasil Uji Koefisien Determinan Model Summary

\begin{tabular}{ccccc}
\hline Model & $\boldsymbol{R}$ & $\begin{array}{c}\boldsymbol{R} \\
\text { Square }\end{array}$ & $\begin{array}{c}\text { Adjusted } \boldsymbol{R} \\
\text { Square }\end{array}$ & $\begin{array}{c}\text { Std. Error of the } \\
\text { Estimate }\end{array}$ \\
\hline 1 &, $462^{\mathrm{a}}$ &, 214 &, 120 &, 0619229 \\
\hline
\end{tabular}

a. Predictors: (Constant) BAI, KK, ROE

Berdasarkan Tabel 6 uji koefisien determinan dapat diketahui bahwa nilai Adjusted $R$ Square sebesar 0,120. Nilai tersebut menunjukkan bahwa variabel independen yang terdiri dari biological asset intensity, konsentrasi kepemilikan dan profitabilitas secara simultan memiliki pengaruh yang kecil terhadap variabel dependen yaitu pengungkapan aset biologis sebesar $12 \%$. Sedangkan $88 \%$ terdapat variabel lain yang dapat mempengaruhi variabel dependen.

\section{Pengaruh Biological Asset Intensity Terhadap Pengungkapan Aset Biologis}

Biological asset intensity tidak berpengaruh terhadap pengungkapan aset biologis. Peningkatan biological asset intensity tidak diikuti dengan peningkatan pengungkapan aset biologis. Maka hasil penelitian ini tidak mendukung hipotesis pertama. Besarnya biological asset intensity pada perusahaan agrikultur tidak menjamin keluasan pengungkapan aset biologis yang dilakukan oleh perusahaan tersebut. Hasil penelitian ini sejalan dengan penelitian yang menyatakan bahwa 
biological asset intensity tidak berpengaruh terhadap pengungkapan aset biologis (Gonçalves and Lopes 2014; Alfiani and Rahmawati 2019; Sa'diyah et al. 2019; Aliffatun and Sa'adah 2020). Sedangkan penelitian yang tidak sejalan dengan hasil penelitian ini menyatakan bahwa biological asset intensity berpengaruh terhadap pengungkapan aset biologis (Yurniwati et al. 2018; Putri and Siregar 2019; Hayati and Serly 2020; Azzahra et al. 2020).

\section{Pengaruh Konsentrasi Kepemilikan Terhadap Pengungkapan Aset Biologis}

Konsentrasi kepemilikan tidak berpengaruh terhadap pengungkapan aset biologis. Peningkatan konsentrasi kepemilikan tidak diikuti dengan peningkatan pengungkapan aset biologis. Maka hasil penelitian ini mendukung hipotesis kedua. Perusahaan dengan kepemilikan terkonsentrasi tidak terlalu memperhatikan pengungkapan aset biologis untuk diungkapkan dalam laporan keuangan tahunan karena dianggap tidak terlalu penting. Hasil penelitian ini sejalan dengan penelitian yang menyatakan bahwa konsentrasi kepemilikan tidak berpengaruh terhadap pegungkapan aset biologis (Gonçalves and Lopes 2014; Daly and Skaife 2016; Yurniwati et al. 2018; Cavalheiro et al. 2019; Alfiani and Rahmawati 2019; Putri and Siregar 2019). Sedangkan penelitian yang tidak sejalan dengan penelitian ini menyatakan bahwa konsentrasi kepemilikan berpengaruh terhadap pegungkapan aset biologis (Riski et al. 2019; Aliffatun and Sa'adah 2020; Azzahra et al. 2020).

\section{Pengaruh Profitabilitas Terhadap Pengungkapan Aset Biologis}

Profitabilitas tidak berpengaruh terhadap pengungkapan aset biologis. Peningkatan profitabilitas tidak diikuti dengan peningkatan pengungkapan aset biologis. Maka hasil penelitian ini mendukung hipotesis ketiga. Tinggi atau rendahnya profitabilitas yang dicerminkan oleh perbandingan laba bersih setelah pajak dan total ekuitas yang dimiliki perusahaan agrikultur tidak menjadi faktor pendorong perusahaan untuk melakukan pengungkapan aset biologisnya. Hasil penelitian ini sejalan dengan penelitian yang menyatakan bahwa profitabilitas tidak berpengaruh terhadap pengungkapan aset biologis (Gonçalves and Lopes 2014; Daly and Skaife 2016; Selahudin et al. 2018; Cavalheiro et al. 2019; Alfiani and Rahmawati 2019; Gustria and Sebrina 2020). Sedangkan penelitian yang tidak sejalan dengan penelitian ini menyatakan bahwa profitabilitas berpengaruh terhadap pengungkapan aset biologis (Riski et al. 2019).

\section{KESIMPULAN}

Berdasarkan hasil pengujian yang telah dilakukan, maka diperoleh kesimpulan bahwa Biological Asset Intensisty tidak berpengaruh terhadap Pengungkapan Aset Biologis. Konsentrasi Kepemilikan tidak berpengaruh terhadap Pengungkapan Aset Biologis. Profitabilitas tidak berpengaruh terhadap Pengungkapan Aset Biologis.

Keterbatasan dalam penelitian ini yaitu tidak semua laporan keuangan tahunan yang dipublikasikan oleh perusahaan agrikultur menyajikan informasi terkait variabel penelitian dan item-item pengungkapan yang terdapat dalam PSAK 69 belum sepenuhnya diungkapkan oleh perusahaan agrikultur.

Untuk penelitian selanjutnya diharapkan menguji variabel lain yang 
mungkin berpengaruh terhadap pengungkapan aset biologis, seperti tingkat internasionalisasi dan leverage, selain itu juga bisa menjadikan salah satu dari variabel dalam penelitian ini menjadi variabel mediasi. Untuk penelitian selanjutnya pengamatan diharapkan menggunakan tahun yang terbaru dan memperpanjang tahun pengamatan penelitian agar dapat memberikan gambaran terkini mengenai pengungkapan aset biologis.

\section{DAFTAR PUSTAKA}

Alfiani, Linda Kurnia and Evi Rahmawati. 2019. "Pengaruh Biological Asset Intensity, Ukuran Perusahaan, Pertumbuhan Perusahaan, Konsentrasi Kepemilikan Manajerial, Dan Jenis KAP Terhadap Pengungkapan Aset Biologis (Pada Perusahaan Agrikultur Di BEI Periode 2014-2017)". Reviu Akuntansi dan Bisnis Indonesia 3 (2): 163-178. https://doi.org/10.18196/rab.030243.

Aliffatun, Annisa, and Lailatus Sa'adah. 2020. "Pengaruh Intensitas asset Biologis, Ukuran Perusahaan dan Konsentrasi Kepemilikan Manajerial Terhadap Pengungkapan Asset". JIATAX: Journal of Islamic Accounting and Tax 3 (1): 18.

Azzahra, Viona, Elvira Luthan and Amy Fontanella. 2020. "Determinan Pengungkapan Aset Biologis (Studi Empiris pada Perusahaan Agriculture yang Terdaftar di Bursa Efek Indonesia)". Ekonomis: Journal of Economics and Business 4 (1): 230-240. http://dx.doi.org/10.33087/ekonomis.v4i1.114.

Birch, Kean, and David Tyfield. 2012. "Theorizing the Bioeconomy: Biovalue, Biocapital, Bioeconomics or . . . What?" Science Technology and Human Values 38 (3): 299-327. https://doi.org/10.1177/0162243912442398.

Bohušová, Hanam, and Patrik Svoboda Bohusova. 2016. "Biological Assets: In What Way Should Be Measured by SMEs?" Procedia - Social and Behavioral Sciences 220: 62-69. https://doi.org/10.1016/j.sbspro.2016.05.469.

Cavalheiro, Rafael Todescato, Régio Marcio Toesca Gimenes, Erlaine Binotto, and Carlos Ricardo Fietz. 2019. "Fair Value of Biological Assets: An Interdisciplinary Methodological Proposal". Revista de Administração Contemporânea 23 (4): 543-63. https://doi.org/10.1590/19827849rac2019180254.

Daly, Abbie, and Hollis A. Skaife. 2016. "Accounting for Biological Assets and the Cost of Debt". Journal of International Accounting Research 15 (2): 31-47. https://doi.org/10.2308/jiar-51335.

Duwu, Marselina Inggrid, Sylvia Christina Daat, and Hastutie N. Andriati. 2018. "Pengaruh Biological Assets Intensity, Ukuran Perusahaan, Konsentrasi Kepemilikan, Jenis KAP, Dan Profitabilitas Terhadap Biological Asset Disclosure (Pada Perusahaan Agrikultur Yang Terdaftar Di Bursa Efek Indonesia Periode 2012-2016)". Jurnal Akuntansi \& Keuangan Daerah 13 (2): 56-75.

Freeman, R. Edward, and John McVea. 2005. A Stakeholder Approach to Strategic Management. The Blackwell Handbook of Strategic Management. Wiley Online Library. https://doi.org/10.1111/b.9780631218616.2006.00007.X. 
Gonçalves, Rute, and Patrícia Lopes. 2014. "Firm-Specific Determinants of Agricultur Financial Reporting". Procedia - Social and Behavioral Sciences 110: 470-481. https://doi.org/10.1016/j.sbspro.2013.12.891.

Gustria, Usi and Nurzi Sebrina. 2020. "Pengaruh Profitabilitas, Ukuran Perusahaan, Dan Jenis Kap Terhadap Pengungkapan Aset Biologis". JEA: Jurnal Eksplorasi Akuntansi 2 (1): 2362- 2372.

Hayati, Kurnia, and Vanica Serly. 2020. "Pengaruh Biological Asset Intensity, Growth, Leverage, Dan Tingkat Internasional Terhadap Pengungkapan Aset Biologis". JAE: Jurnal Eksplorasi Akuntansi 2 (2): 2638-2658.

Ikatan Akuntan Indonesia. 2018. Pernyataan Standar Akuntansi Keuangan (PSAK) No.69: Agrikultur. Jakarta: IAI.

Mondelli, Mario P., and Peter G. Klein. 2014. "Private Equity and Asset Characteristics: The Case of Agricultural Production". Managerial and Decision Economics 35 (2): 145-160. https://doi.org/10.1002/mde.2649.

Obst, Carl, and Michael Vardon. 2014. "Recording Environmental Assets in the National Accounts". Oxford Review of Economic Policy 30 (1): 126-144. https://doi.org/10.1093/oxrep/gru003.

Putri, Monica Okri, and Nolita Yeni Siregar. 2019. "Pengaruh Biological Asset Intensity, Ukuran Perusahaan, Kepemilikan Manajerial, Dan Jenis Kap Terhadap Pengungkapan Aset Biologis". Jurnal Akuntansi \& Keuangan 10 (2): 44-70. http://dx.doi.org/10.36448/jak.v10i2.1288.

Riski, Tiara, Diyah Probowulan, and Retno Murwanti. 2019. "Dampak Ukuran Perusahaan, Konsentrasi Kepemilikan Dan Profitabilitas Terhadap Pengungkapan Aset Biologis". JOISH: Jurnal Ilmu Sosial dan Humaniora 8 (1), 60-71. http://dx.doi.org/10.23887/jish-undiksha.v8i1.21355.

Sa'diyah, Lentina Diah Jamilatus, Muhaimin Dimyati, and Wahyuning Murniati. 2019. "Pengaruh Biological Asset Intensity, Ukuran Perusahaan, dan Tingkat Internasionalisasi Terhadap Pengungkapan Aset Biologis (Pada Perusahaan Agrikultur Yang Terdaftar Di Bursa Efek Indonesia Periode 2013-2017)". Proceedings Progress Conference 2 (1): 291-304.

Selahudin, Nor Farhana, Fatin Najwa Muhammad Firdaus, Nur Shahira Aida Mohd Sukri, Shamini Naidu Gunasegran, and Siti Fadzilah Abd Rahim. 2018. "Biological Assets: The Determinants of Disclosure." Global Business and Management Research: An International Journal 10 (3): 170-179.

Yurniwati, Amsal Djunid, and Frida Amelia. 2018. "Effect of Biological Asset Intensity, Company Size, Ownership Concentration, and Type Firm against Biological Assets". The Indonesian Journal of Accounting Research 21 (1): 121-146. http://doi.org/10.33312/ijar.338. 